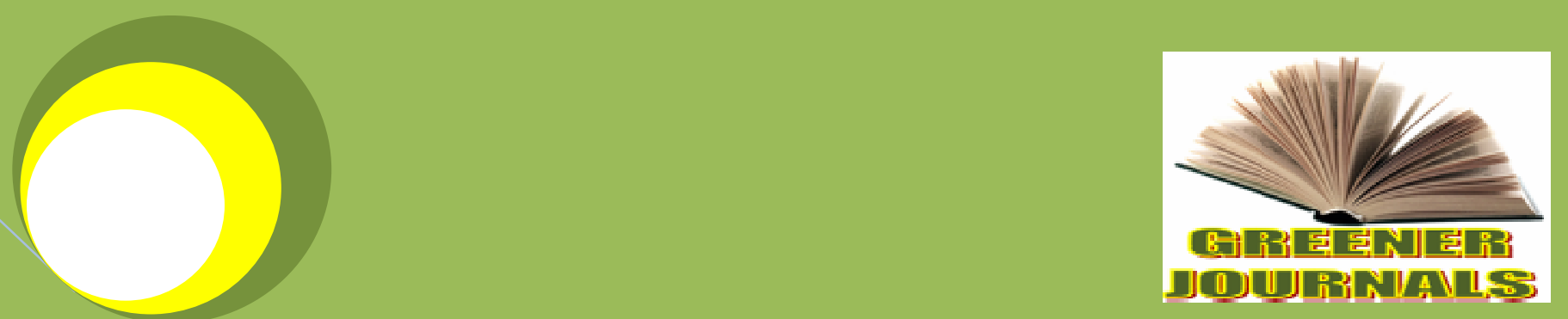

Greener bournal of Businessand ManayementStudies ISSN: $2276-7827 \quad$ ICV: 6.02

Marketing Warfare in the Hospitality

Industry: A Case Study of Selected Hotels in Harare, Zimbabwe By

Chikosha Felix Chiunye Tonderai Maximilian 
Research Paper (DOI: http://doi.org/10.15580/GJBMS.2015.1.0307141345)

\title{
Marketing Warfare in the Hospitality Industry: A Case Study of Selected Hotels in Harare, Zimbabwe
}

\author{
${ }^{* 1}$ Chikosha Felix and ${ }^{2}$ Chiunye Tonderai Maximilian
}

\author{
${ }^{1}$ Department of Business Management, Zimbabwe Open University, 209 Hay Road Bindura, Zimbabwe. \\ ${ }^{2}$ Department of Business Management, Zimbabwe Open University, 209 Hay Road, Bindura, Zimbabwe.
}

*Corresponding Author's Email: frixch@hotmail.com

\begin{abstract}
The study investigated on the competitive rivalry amongst selected hotels in Harare with a broad aim of determining their competitive profiles. A company' competitive profile can be market leader, market challenger, market follower or market nicher. Four major hotel groups in Harare were taken for the study and these are; Meikles, Rainbow Towers, African Sun and Cresta Hospitality. African Sun is represented by its flagship hotels: Holiday Inn and Crown Plaza whereas Cresta has Cresta Jameson and Cresta Jameson. A mixed research design methodology was used; the quantitative and qualitative the research approaches. For the quantitative research a total of 25 hotel guests were taken per each hotel to measure satisfaction with hotel services. The data was collected through questionnaires with structured questions. Documentary evidence was used for the qualitative approach. Information on market share, profitability, average room rates and room occupancy was sought from published sources. The study revealed that African Sun is the leading firm with a market share of $35 \%$.The market challenger turned out to be Rainbow Towers whilst Cresta Jameson assumed the market follower status. Meikles stood out to be a market nicher.
\end{abstract}

Key Words: Marketing Warfare, Competitive profile, Hospitality Industry.

\section{INTRODUCTION}

The hospitality industry is one of the key sectors to the revival of the Zimbabwe economy which is reeling from decade decay, triggered by the chaotic land reform. Emerging from economic woes, it is not surprising companies and individuals are still struggling and this has direct bearing on hotel business which is more often taken as a luxury. There is intense competition amongst hotels for the little business that is there. From rebranding activities, facelifts, promotions, to major investments players in the hotel industry are trying to outwit each other in the quest for market share. The paper seeks to explore the marketing warfare amongst the four main hotel groups in Harare; Meikles, African Sun, Cresta Hospitality.

Marketing Warfare is a term used in business and marketing, that tries to draw the parallels between business and warfare and then try to apply the principles of military strategy to business situations. Ries and Trout (1999) argue that marketing is a war and the marketing concept's customer-oriented philosophy is inadequate. Rather, firms would do better by becoming competitor oriented. The researcher's keenness to study the competitive rivalry in the hospitality industry is spurred by the fact that to date studies on the hospitality industry has largely been confined to hotels and their link with tourism. Little attempt had been made to look at competitive rivalry as it pertains to hotels.

\section{Literature Review}

\section{Competitive strategies according to market position}

According to the market position occupied by a firm (organization) the following market structure can be mentioned: $40 \%$ is held by the market leader, $30 \%$ is held by the market challenger, $20 \%$ is held by the market follower and $10 \%$ is held by the market nichers (Kotler \& Keller, 2006). These four positions held by the firms (organizations) on the market assume different strategies. 


\section{Market Leader}

According to Aacker (1992), the market leader has a large market share in are relevant product market. Du Plessis et al (200l) specify that the market share should be approximately $40 \%$ and above. The market leader determines the nature, pace and bases of competition by virtue of its pricing, advertising intensity, distribution coverage, new product introduction among other things.

Dibb et al (1994) postulates that, in the world of market shares, there has to be one and only one market leader: the player enjoying individually the largest slice of the market. The market leader has the highest market share and retains its competitive position by expanding the total market or expanding share at the expense of its rivals, while protecting or defending current marketing share by retaining its customer base.

\section{Market challengers}

Cole et al (1998) postulate that market challengers are non-market leaders that aggressively attack rivals, including the market leader to take more market share. In most instances these players are number two, three and perhaps four in a market, aspiring to market leadership.

\section{Market followers}

According to Aacker (1992) market followers are low share competitors without the resources, market position, research and development, or commitment to challenge for extra sales and market share. These companies tend to be the "plodders" or "me too" in a market.

\section{Market Nichers}

Dibb et al (1994) propounds that market nichers focus on only a very narrow range of products or on a selected band of consumers. Nichers survive by finding a safe, small, profitable market segment often apparently too small to attract the market leaders and challengers.

Baban (2013) summarily put it that a market leader implements strategies in order to expand global market by diversifying its product range and creating innovative products. Firms ranked second (challenger) are trying to expand market share by using offensive strategies and firms ranked third and fourth, respectively follower firms and small companies (nicher) take a fight for survival, trying to maintain position market by using competitive strategies in order to attract new customers.

\section{Competitive strategy in the hospitality industry}

According to Nyheim (2004), the key to attracting and making clients loyal is offering an unforgettable experience and not just accommodation; hotel chains innovate to create a unique environment, from hotel rooms to lobbies and the restaurant.

Along with innovation, technology is an important strategic asset that allows hotel chains to improve their performance and competitiveness. On a global scale, the role of technology in strengthening the competitive advantage of a hotel is recognized, hence its contribution to the hotel's success (Nyheim, 2004).

Since the hospitality industry, as any other branch of services, is capital intensive, human resources can represent a source of competitive advantage for a company. Ireland (2005), in the research conducted among 3, 4 and 5 star hotels in Dublin to analyze successful practices in hotels underline the fact that the industry depends on the know-how of personnel, of the knowledge and understanding of the clients' requirements that would make the client feel at home.

Another source of competitive advantage can be found in the management of the acquisition-delivery chain. As Harold Sirkin notes for the Boston Consulting Group: the acquisition-delivery chain can enhance the performance of a company by developing advantages in specific sequences: quality, trust, flexibility, agility and cost efficiency. The achievement of improvements by observing this order will ensure long term benefits that will offer a sound foundation for future improvement initiatives and a chain to successfully deal with future challenges (Nyheim, 2004).

\section{Competitive advantage and Market Share}

Since competitive advantage is built on Porter's three generic strategies of cost leadership, differentiation, and focus, so therefore is market share (Porter, 1985). The successful application of these grand strategies to the marketing mix 
elements has an influence on the choice of strategies and actions to be used in 'positioning' the 'offer' (product, service, price and communication message) for effective market share gain. In cost leadership, a firm sets out to be the lowest-cost producer and consequently the price giver in its industry. It is therefore capable of building its market share by offering lower prices relative to its competitors. In focus strategy, a firm or a product line is tailored to meet identifiable needs only of a specific niche that are poorly met or not served at all. In this way, it is able to capture higher share of the target segment. On the other hand, a firm pursuing differentiation (or product leadership) strategy seeks to be unique in its industry along one or a few dimensions that are widely valued by customers, subsequently attaining higher market share (Porter, 1985). Aaker \& Day (1986) as well as Peters \& Waterman (1982), Clifford \& Cavanagh (1985), and Peters \& Austin (1985) argue that competitive advantage built around product benefits (differentiation) rather than low-cost or time of entry is the most critical determinant of success in share growth in brand markets.

\section{MATERIALS AND METHODS}

The study was delimited to the competitive rivalry between four leading hotels in Harare, the capital city of Zimbabwe. They are Rainbow Towers, African Sun, Meikles and Cresta Jameson. For the descriptive survey twenty -five (25) guests were conveniently drawn from each of the hotels.

A SERVIQUAL instrument developed by Parasuraman et al (1988) was modified to capture customer perceptions on how well the hotels are providing services. The researchers modified Parasuraman' SERVIQUAL instrument to include the following dimensions: customer service, facilities, food quality affordability and recreational activities. Ratings were done on a five point likert scale ranging from 1 (poor) to 5 (excellent). The mid level of the likert scale of 2.5 was used to categories the respondents' overall perception of service quality. Levels $>2.5$ signify high customer satisfaction and levels $<2.5$ low customer satisfaction.

Documentary analysis was used to collect secondary data on the hotels performances. Company internal records and commercial reports provided data for the desk research.

\section{RESULTS AND DISCUSSION}

Table 1: Customer satisfaction on service aspects

\begin{tabular}{|l|l|l|l|l|l|l|}
\hline \multirow{2}{*}{ Service Aspect } & \multicolumn{6}{|c|}{ Customer Satisfaction means } \\
\cline { 2 - 7 } & $\begin{array}{l}\text { Rainbow } \\
\text { Towers }\end{array}$ & \multicolumn{2}{|l|}{ African Sun } & \multicolumn{2}{l|}{ Cresta Hospitality } & $\begin{array}{l}\text { Meikles } \\
\text { Group }\end{array}$ \\
\hline & $\begin{array}{l}\text { Rainbow } \\
\text { Hotel }\end{array}$ & $\begin{array}{l}\text { Holiday } \\
\text { Inn }\end{array}$ & $\begin{array}{l}\text { Crown } \\
\text { Plaza }\end{array}$ & $\begin{array}{l}\text { Cresta } \\
\text { Lodge }\end{array}$ & $\begin{array}{l}\text { Cresta } \\
\text { Jameson }\end{array}$ & Meikles \\
\hline Customer service & 3.02 & 4.12 & 4.12 & 3.12 & 3.52 & 4.04 \\
\hline Food quality & 4.49 & 4.52 & 4.54 & 3.70 & 3.80 & 4.02 \\
\hline Facilities & 3.74 & 4.64 & 4.54 & 3.90 & 3.71 & 4.74 \\
\hline Affordability & 4.12 & 4.02 & 4.12 & 4.82 & 4.84 & 3.02 \\
\hline Recreational activities & 4.59 & 4.60 & 4.44 & 3.02 & 3.12 & 3.44 \\
\hline Weighted Average & 3.99 & 4.38 & 4.35 & 3.71 & 3.80 & 3.85 \\
\hline
\end{tabular}

The results in Table 1 reveal that despite varying levels of satisfaction with different service aspects all guests were overally satisfied. African Sun hotel guests where however the most satisfied followed by Holiday Inn and Crown Plaza. Rainbow Towers follow, then Meikles, and lastly Cresta Hospitality Hotels. African Sun dominates other hotels on customer service, food quality, facilities and recreational activities. Rainbow closely follow and even parallel African Sun on recreational activities. Meikles does well but is rated negatively on affordability. Cresta lags behind in all aspects but is in terms of affordability. 
Hotel performance Indices

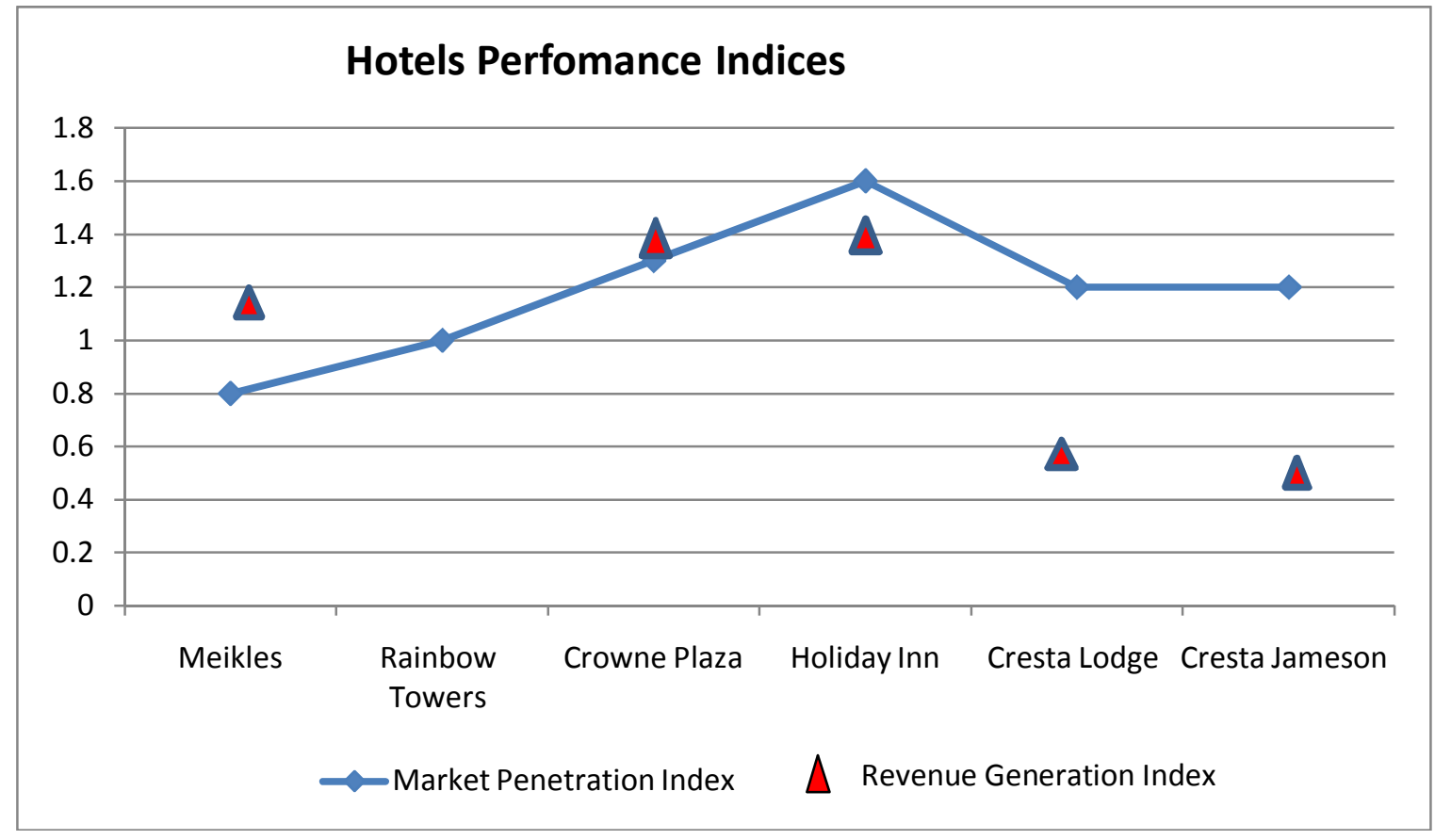

Figure 1: Revenue and Market penetration

Source: Imara Edwards Securities (IES)

Figure 1 highlight hotel performance on a set of indices. From Figure 1, African Sun hotels; Crown Plaza and Holiday Inn have the highest return on investment (ROI).Meikles follow, then Rainbow Towers and lastly Cresta Hospitality. On market penetration, African Sun has made the biggest inroad in the market, followed by Cresta Hotels, then Rainbow Towers and Cresta Hospitality at last.

\section{Harare Hoteliers' Average Daily Rate}

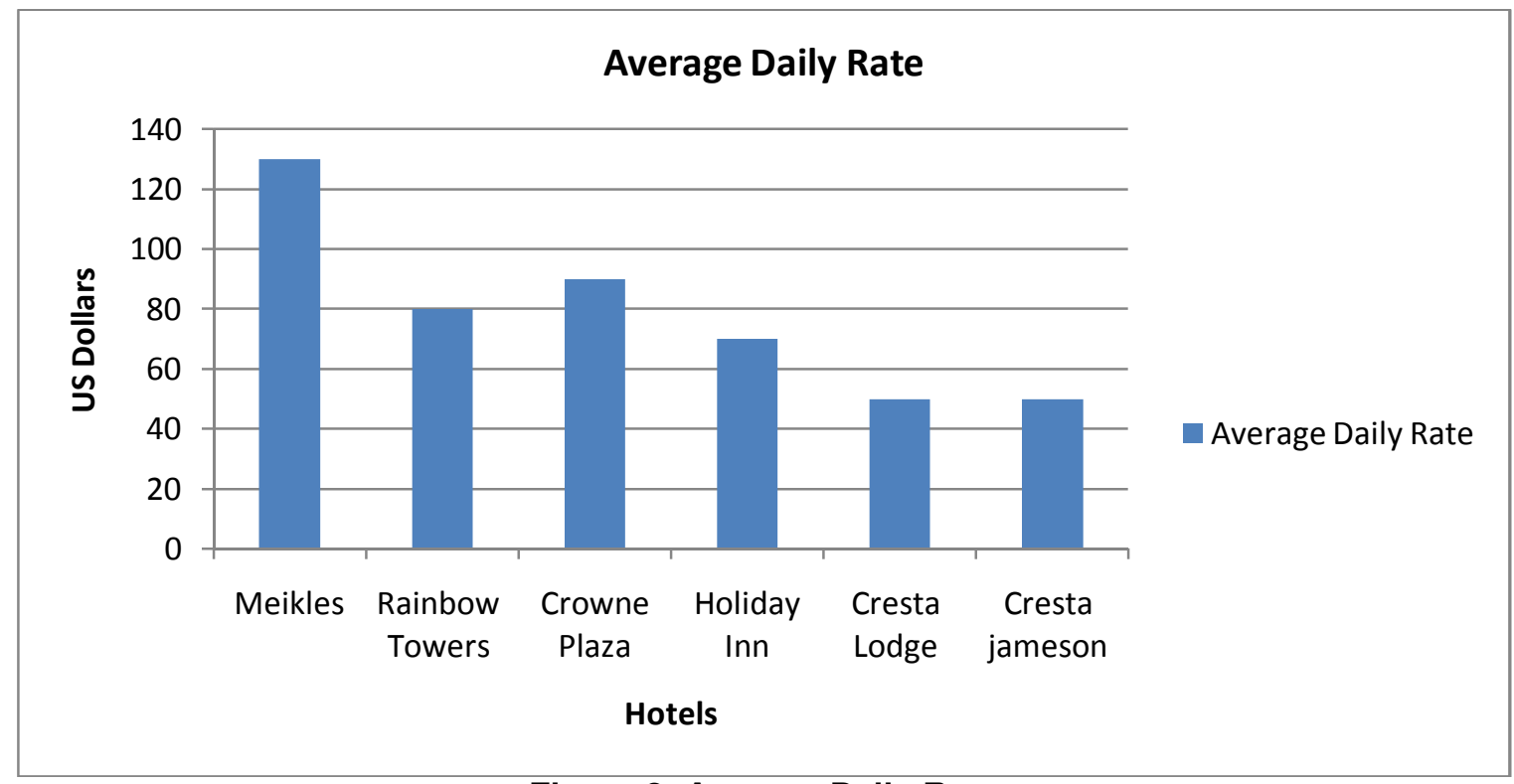

Figure 2: Average Daily Rate

Source: Imara Edwards Securities (IES) 
Figure 2 reveals that Cresta Hospitality has the least average room prices ( $\$ 50-\$ 60)$.African Sun and Rainbow have more or less same prices, between $\$ 70$ and $\$ 90$. Meikles charges an astronomical average $\$ 130$ per room.

\section{Hotel market share}

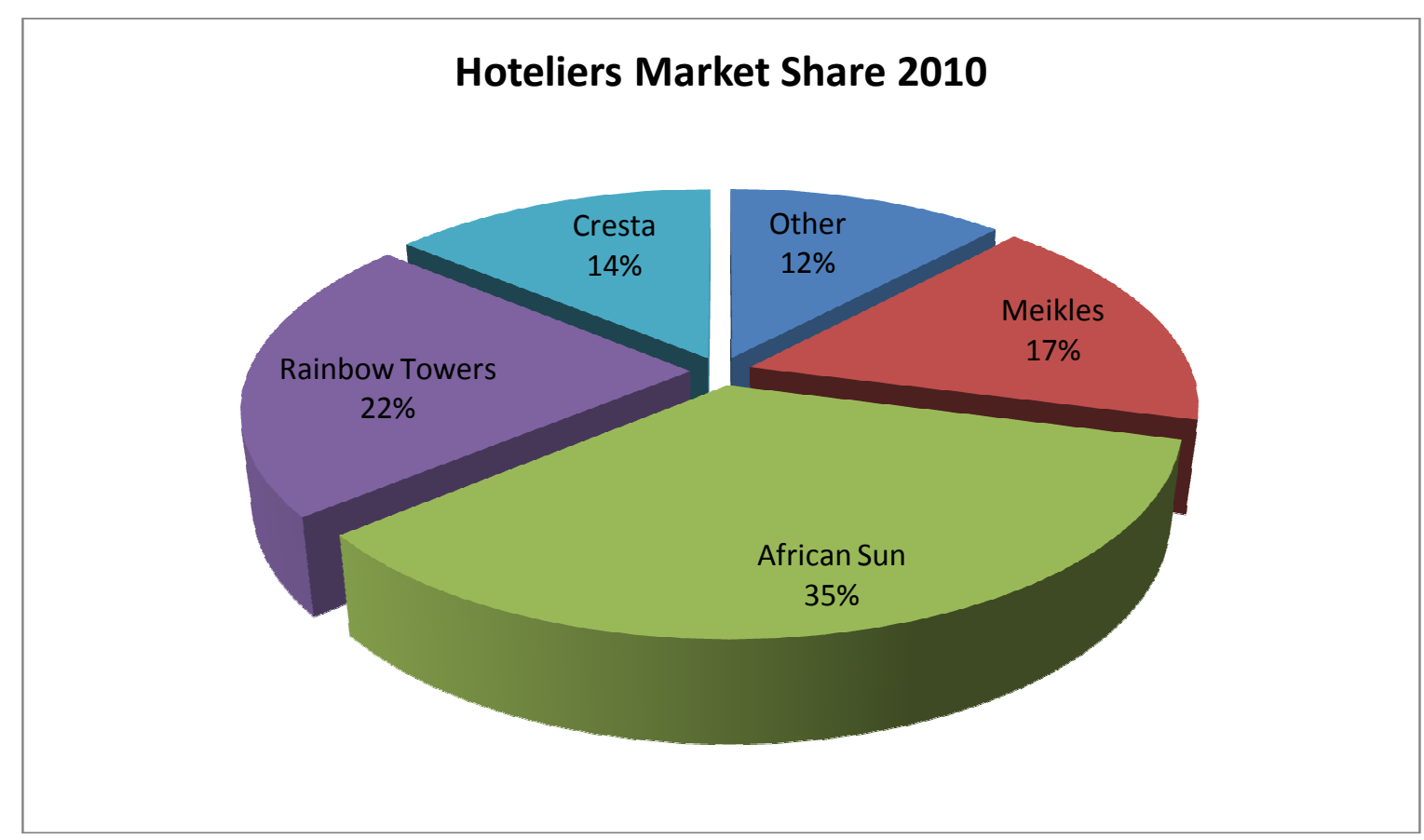

Figure 3: Hotel Market Share

Source: Imara Edwards Securities (IES)

Figure 3 reveals African Sun leads in market share (35\%). The group is 5\% short of the required $40 \%$ to be the undisputed market leader. Rainbow Towers is in second place with $22 \%$ market share. Meikles is next at $17 \%$, and then Cresta Hospitality is last with $14 \%$.

Studied with guest satisfaction levels in Table 1 and performance indices in Figures 1 and 2, African Sun is clearly the market leader. It tops all hotels on performance and leads in providing quality services through excellent customer service, superior facilities and a variety of recreational activities. Rainbow though behind is close in all aspects to African Sun. Cresta has the lowest market share despite its low prices. It also has the least return on investment. Meikles has a sizeable market share despite charging astronomical rates. Its strategy is to provide quality services at a premium to well to do clientele.

\section{CONCLUSIONS}

African Sun is the undisputed market leader in the hotel industry in Harare. The group has the largest market share and leads ratings on service provision. It also has the highest return on investment. Rainbow is the market challenger. It is so close on all measured aspects to the leader. Cresta seem not be aggressive, it is a market follower. Meikles is bent on proving quality services at premium rates. It reveals all aspects of a market nicher.

\section{COMPETING INTERESTS}

There are no competing interests adjudged in this study. 


\section{AUTHORS' CONTRIBUTIONS}

The corresponding author was involved in all activities from conceiving and designing the study, data acquisition, data analysis and interpretation and drafting of the final article. The co-author assisted from data analysis to the drafting of the final article.

\section{ACKNOWLEDGEMENTS}

The authors are quite grateful to the management of the selected hotel groups; African Sun, Rainbow Towers, Meikles and Cresta Hospitality for allowing them to carry out research on their organisations.

\section{REFERENCES}

Aaker, D. A., Day, G.S. (1986) The Perils of High-Growth Markets, Strategic Management Journal Vol. 7, pp409-421 Aacker, D.A (1992) $3^{\text {rd }}$ Edition, Strategic Marketing Management John Willy and Sons

Baban, E.G (2013). Competitive Strategies in the Context of Political marketing ideas.repec.org/a/but/manage/v17y2013i1p175-179.html

Cavanagh, R. E., Clifford, D. K., (1985), "The Winning Performance: How America's High- and Midsize Growth Companies Succeed," New York: Bantam Books.

Cole D., Bandi L., Langely E (1998) $6^{\text {th }}$ Edition, Management of Business, West Publishing Company, London

Dibb R, Smith A, Pride F., Ferrel E. (2001), Marketing Concepts and Strategies, 4th Edition, Houghton Miffin. Boston Duplessis, PJ (2001), Applied Strategic Marketing, Heinemann

Kotler, P., Keller, K.L. (2006), Marketing Management Twelfth ed., Pearson Practice Hall, New Jersey.

Ireland F (2005), A Human Resource Development Strategy for Irish Tourism: Competing Through People, Failte Ireland, Dublin

Imara Edwards Securities (IES).Zimbabwe Hospitality Sector-Undeniable long term value given the countries tourism assets.imara.co/uploads/stockbroking/Africa-securities/February 2011.pdf

Rise A., Trout J (1999), Positioning the Battle for Your Mind, New York: McGraw-Hill

Nyheim, P., McFadden, F., and Connolly, D. (2004). Technology Strategies for the Hospitality Industry. New Jersey NJ: Pearson Prentice-Hall.

Parasuraman, A., Zeithmal, V.A., Berry, L.L. (1988). SERVIQUAL: a multi-item scale for measuring customer perception of service quality. Journal of Retailing, 64(1): 12-40.

Porter, M.E., (1985), "Competitive Advantage: Creating and Sustaining Superior Performance," New York: Free Press.

Peters, T., Austin, N. (1985) "A passion for excellence." Glasgow: Fontana/Collins.

Peters, T., Waterman, R .H. (1982). "In search of excellence." New York.

Cite this Article: Chikosha F, Maximilian CT, 2015. Marketing Warfare in the Hospitality Industry: A Case Study of Selected Hotels in Harare, Zimbabwe, Nigeria. Greener Journal of Business and Management Studies, 5(1):031-036, http://doi.org/10.15580/GJBMS.2015.1.0307141345. 